\title{
CONTRADICTORY TENDENCIES IN ITALY'S IMMIGRATION POLICIES: \\ A CONTEMPORARY ANALYSIS
}

\begin{abstract}
By
Priscillia Darcy

BA Spanish and Latin American Studies, Dalhousie University, 2018; Certificate in Intercultural Communications, Dalhousie University, 2018
\end{abstract}

\author{
A Major Research Paper \\ presented to Ryerson University
}

in partial fulfillment of the requirements for the degree of

Master of Arts

in the program of

Immigration and Settlement Studies

Toronto, Ontario, Canada, 2020

(C) Priscillia Darcy 2020 


\section{Author's Declaration}

I hereby declare that I am the sole author of this MRP. This is a true copy of the MRP, including any required final revisions. I authorize Ryerson University to lend this MRP to other institutions or individuals for the purpose of scholarly research I further authorize Ryerson University to reproduce this MRP by photocopying or by other means, in total or in part, at the request of other institutions or individuals for the purpose of scholarly research. I understand that my MRP may be made electronically available to the public. 


\title{
CONTRADICTORY TENDENCIES IN ITALY'S IMMIGRATION POLICIES:
}

\section{A CONTEMPORARY ANALYSIS}

\author{
Priscillia Darcy \\ Master of Arts 2020 \\ Immigration and Settlement Studies \\ Ryerson University
}

\begin{abstract}
This research paper is an exploratory examination of the complex migrant situation in Italy. Beginning with a historical-comparative examination of how Italy's migration policies and laws evolved over the years, informing the current situation concerning the country's management of migration flows and the subsequent treatment of migrants arriving to its coasts, before finally discussing the most recent rise of the right, and anti-migrant policies. It identifies the current and most controversial topics concerning the region; Italy's management and the problematic treatment of migrants arriving to its coasts and the eroding relationship between the country and the rest of the international community as it deals with the continuing challenge.
\end{abstract}

Key words: Italy, immigration policy, migration, migration management, European migration flows, Europe, European Union migration policies. 


\section{Acknowledgements}

I would like to thank my supervisor, Dr. Tariq Amin-Khan, of the Department of Politics and Public Administration of Ryerson University, for his continuous support and patience in this process. I would like to also thank my Second Reader, Dr. Myer Siemiatycki, of the Department of Politics and Public Administration of Ryerson University, for accepting the former task and

for his flexibility in working with Dr. Amin-Khan and myself. Finally, a special thank you to my past professor and friend Dr. Christopher Helland for his writing support and constructive comments. 


\section{Table of Contents}

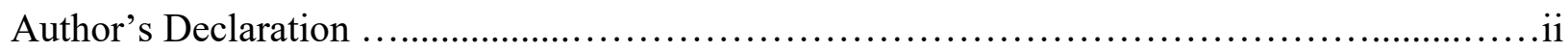

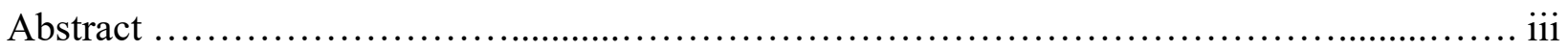

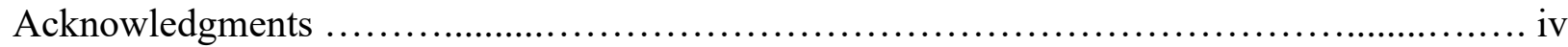

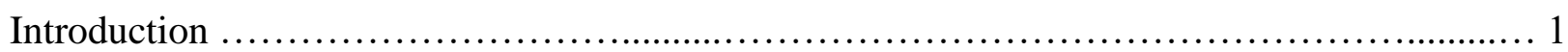

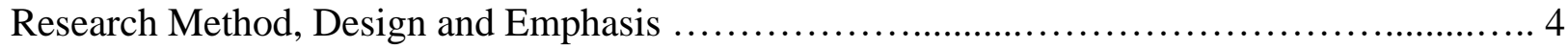

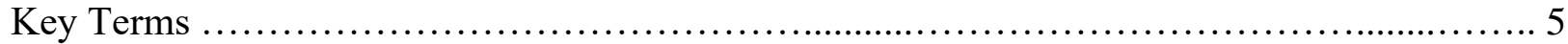

Literature Review Part 1: The Evolution of Italy's Migration Policies and Laws....................... 7

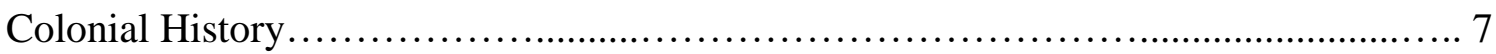

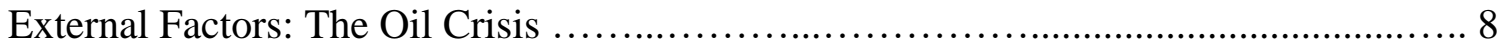

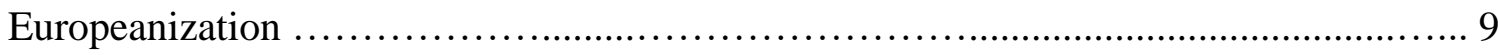

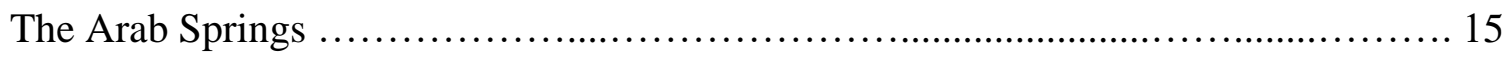

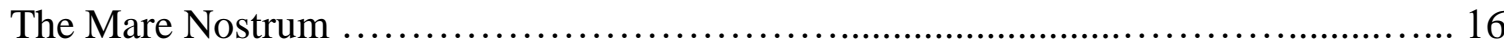

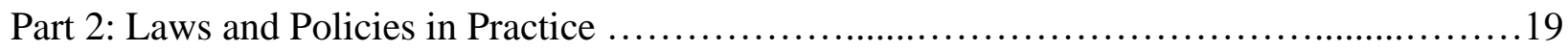

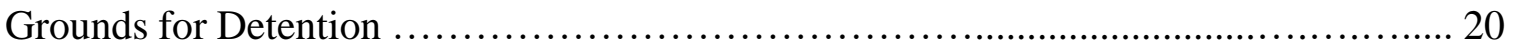

Detentions: Procedural Violations .............................................................................. 21

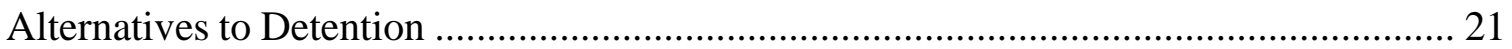

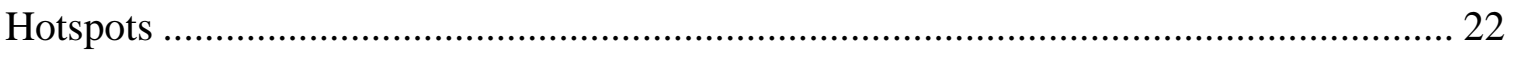

Identification Practices in Hotspots ………………....................................... 24

Corruption in Hotspots and other immigration centers that results in mistreatments........25

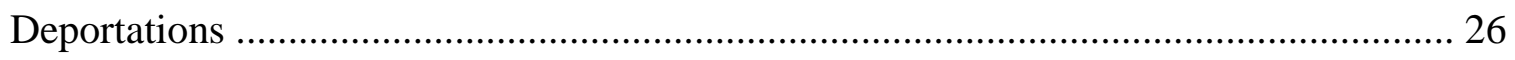

Working with Repressive Governments .................................................................... 27

Lack of Integration Framework ……………………………………………….... 27

Part 3: Recent Developments

The Salvini Government and the Rise of Anti-Migrant Sentiment................................... 29

The Salvini Safety Decree ………………………….................................................. 32

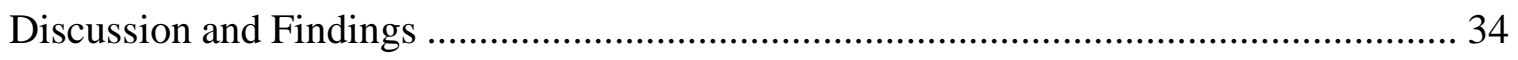

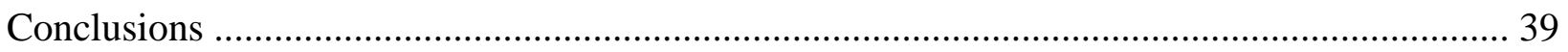

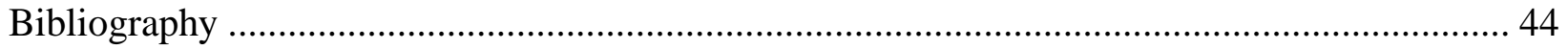




\section{Introduction}

For any academic interested in asylum policy and human displacement, Europe is certainly an area of study of choice. Its closeness to Africa - and by extension to the Middle-East - where wars and poverty continue to displace hundreds of thousands of human beings every year, as well as its many strong colonial ties to Africa have made it the (only) destination of choice of migrants escaping all sorts of precarious situations in their origin countries. What makes Italy stand out as a potential case study, however, is the fact that the country seems to be unsure about, and thus, "playing both sides", when it comes to their migration policy and their standpoint on asylum seekers. Indeed, contrary to other countries such as Hungary, for example, Italy does have an asylum policy in place; however, whether Italy respects its own policies and laws in practice when it comes to how it treats migrants attaining its shores is a different story.

On April 15, 2014, a ship carrying migrants from Libya capsized and sank off the coast of Italy. It was estimated that over 400 migrants drown while Italy's Coastguard rescued 144. As this tragedy unfolded through the media, I was stunned by the enormity of the situation. It was reported in the Guardian that the International Organization for Migration in Italy (IOM) believed that 3,072 migrants died in the Mediterranean in 2014 while only 700 had died in 2013. But in total, 22,000 migrants have lost their lives trying to reach Europe since the year 2000 (Gayle, 2015). The Italian Government also stated that between Friday and Monday of the week of April 15 they had rescued 8,500 migrants at sea, "reigniting a debate in Italy about whether the country has a duty to house all new arrivals" (Gayle, 2015). Due to the geographical location of Italy in the Mediterranean, it is arguably one of the countries most affected by the migration crisis in the European Union. 
As more media reports emerged about the event, certain factors seemed to be presented as the cause of migratory influx. For the most part, these focused upon the political situation in Libya, turmoil in parts of Africa, and the political and state issues of the European Union and the Italian Government. Since media has different ideological leanings, as I began my research for this project, I purposefully chose to step back from any predetermined ideas about the migrant situation in Italy and approached the material I could find on this topic with an open mind. The situation seemed extremely complex, with multiple factors that may have been the causes and multiple factors that may help or hinder the crisis. This necessitated that I do not approach the material from a deterministic perspective, for instance focused upon the role of conflict and war, but rather remained open and utilized a more inductive approach. An inductive approach requires the researcher to begin with observations, exploring the material and data that emerges and then determine which grounded theory is best fitted for the situation being explored. "Thus, one observes, induces empirical generalizations on the basis of these observations, and then, through the process of analytical induction, attempts to develop a full-blown theory that reflects adequately the observed reality" (Palys, 1992, p. 405).

This research paper is an exploratory examination of the complex migrant situation in Italy. Therefore, using a more observational, bottom up approach allowed for the information that was collected to speak for itself and helped refine my focus. Within the field of immigration and settlement studies, a general understanding of the causes, patterns, as well as of the global reaction to human displacement across the world is necessary for any study. As a form of qualitative, secondary-analysis, this paper is observational and preliminary, laying the groundwork to better understand the prevailing situation and identify patterns and themes, which may become part of a further study. 
For this paper, I began with a historical-comparative examination of how Italy's migration policies and laws evolved over the years, informing the current situation concerning the country's management of migration flows and the subsequent treatment of migrants arriving to its coasts, before finally discussing the most recent rise of the right, and anti-migrant policies. This perspective is crucial not only to a further understanding Italy's current situation, but also provides an essential piece of the puzzle for understanding the larger migration crisis affecting Europe. My research quickly identified the current and most controversial topics concerning the region; namely, Italy's management and the problematic treatment of migrants arriving to its coasts, and the eroding relationship between the country and the rest of the international community as it deals with the continuing challenge. 


\section{Research Method, Design and Emphasis}

For the purposes of this paper, I have conducted a literature review of the most current and relevant material pertaining to the historical evolution of Italy's migration policies and laws, as well as to Italy's present management of migration and of migrants. I utilized scholarly articles, academic journals, as well as non-governmental organization reports, and credible news articles. To ensure the relevancy and credibility of the literature I reviewed, I observed pertinent characteristics such as the date of publishing and the source. Furthermore, I focused on substantive research literature rather than on argumentative articles, and ensured that the reports criticizing Italy's management of migration and of migrants were founded, and made by credible organizations such as the Human Rights Watch and the United Nations. Throughout my examination of these critiques, and having an inductive approach (outlined in the Introduction), I remained open and kept in mind counterbalancing facts such as the sheer size of migration flows into Italy, and the overwhelming realness of the migration crisis of Europe.

As the research unfolded, I have separated it into three parts: (1) the history of Italy's migration policies and related laws, (2) Italy's migration policies and related laws in practice, and finally, (3) the recent developments of the new government and the "Salvini Decree". I have, throughout this paper, identified themes which I have analyzed in order to underline the patterns salient in Italy's management of migration into its country.

Key themes identified in my literature review are: Colonial history, Oil Crisis. Europeanization, The Arab Spring, The Mare Nostrum, Grounds for Detentions, Alternatives to Detention, Detention Procedural Violations, Hot Spots, Identification Practices, Lack of Regulation and Transparency, Treatment of Migrants, Deportations; and, Working with Repressive Governments, and finally, the most recent "Salvini Decree". From my analysis, I identified 4 
general themes and three over-arching characteristics that persisted and influenced Italy's history of migration policy, which are discussed in the conclusion of the paper.

From a methodological perspective, it became clear that the situation is so complex, a multi-disciplinary approach was the best way to move forward with further study. There are different factors affecting migration and the receiving of migrants: political, economic, and even geographic and environmental. Thus, relying on one methodological approach would not allow for a complete, comprehensive analysis. Freeman and Kessler (2008), for example, argue that the Political/State approach and the Economic approach to studying migration have their benefits but also their limitations. While a Political-Economy approach, "combines the economic power of labour-demand theory with state or supra-state political mechanisms which generate (or control) international population movements. Thus, the political economy approach has value for this research, as it "sees the immigration policies of receiving states (or supra-national bodies such as the EU) - quota and admission systems, regulations of entry, duration of stay, work permits, citizenship rights etc. - as directly shaping the volume, dynamics and geographical patterns of international migration flows" (Freeman \& Kessler 2008, p. 665). However, at the same time, the methodology of political economy has limited use here based on its deductive propensities within the larger inductive approach of this paper. For this reason, I decided to move forward with a bottom-up, observational and multi-disciplinary approach to my analysis and study.

\section{Key Terms}

Some of the key terms used in the context of this paper are defined as follows; first, the key term migrants is used throughout to refer to all migrants arriving to coasts of Italy - this includes all classes of migrants: asylum seekers, refugees, as well economic migrants. Secondly, 
the terms migration policies (and laws) are used to refer to all policies and laws relation to, and concerning migration in general - this includes asylum and immigration policies and laws. 


\section{Literature Review}

\section{Part 1: The Evolution of Italy's Migration Policies and Laws}

\section{Colonial History}

Italy’s relatively short colonial history $(1890$ - 1941), which involved colonizing a limited number of countries mainly as part of the infamous Scramble for Africa, is a historical factor that influenced its migration history. It colonized countries in Africa including Libya, Ethiopia, Eritrea, and Somalia, creating close ties that continue to influence the current situation, which I shall discuss throughout this paper. Gaddafi, for example, came to power in Libya - a country with which Italy continues to entertain close ties - as an anti-colonial force but soon lapsed into dictatorship. The turmoil in Libya have, in turn, displaced a great number of migrants for decades already. However, originally, these weaker post-colonial ties, compared to other countries of Europe, was one of the first factors for the Italy's ordinary migration history. Migration patterns in Italy during the twentieth century can be characterised as following a pattern of emigration, rather than an immigration flow; the former being salient in numbers (26 million Italians had emigrated by 1976), compared to the only modest while steady latter flow (Abbondanza, 2017, p. 77).

The established normality of the country's (e)migration flow was reflected in little political attention to immigration itself. The original, less stringent immigration regulations were officially established for the first time by the public security segment of Mussolini's fascist government within the Public Security Code (Testo Unico delle Leggi di Publica Sicurreza TULPS), in the first half of the twentieth century (Abbondanza, 2017, p. 77). The Constitution of the Italian Republic, enacted in 1947, only broadly defined the link between foreign nationals entering Italy and their right to asylum, stating that " $[\mathrm{t}]$ he status of foreigners is regulated by law 
in conformity with international provisions and treaties $[\ldots]$ " and that "a foreigner who $[\ldots]$ is denied the actual exercise of the democratic freedoms guaranteed by the Italian constitution [is entitled] to the right of asylum" (Senate of the Italian Republic, cited in Abbondanza, 2017, p. 77).

\section{External Factors: The Oil Crisis}

From the mid 1970's, developing international shifts began influencing new patterns of migration flows into Italy, forcing the country to develop a response. The 1970's oil crisis caused a wave of migration throughout Europe, with many European nations restricting immigration ${ }^{1}$. This resulted in Italy's immigration balance to become positive from 1974 onwards, with a notable increase towards the end of the decade, and into the 1980's (Tintori \& Romei, ,p. 51). As that first period of increased immigration unfolded for Italy, other external factors fueled by a global economic crisis, political and civil instability in Europe, wars and poverty throughout the African continent, substantially increased streams of migrants - particularly those from African countries (Abbondanza, 2017, p. 78).

Attempts to structure legislation to regulate immigration was a lengthy process with two separate Failed-to-Pass Bills between 1970 and 1986. Delays to gain final approval of an immigration-restricting law (Law 943), passed in 1986, showed Italy’s government's inadequacy and inexperience in regards to migration policies. This caused the majority of the human influx of nearly two decades to be accounted for in terms of irregular, and unaccounted-for immigration

\footnotetext{
${ }^{1}$ As the oil crisis deepened its impact on the economy of many European countries, the later to reduce their need for labour. The European's belief in the ideology of inhibited economic development was greatly weakened, which resulted in countries like Switzerland, Sweden, Germany and France to summon a stop to immigration starting in, and through the years from 1970 to 1975 (Boyle, Halfacree \& Robinson, 1998).
} 
until the first regulations of the Foschi Law (1986) were implemented by the Pentapartito (second government) of Bettino Craxi (Veugelers, 2007, p. 35).

The Foschi Law represented Italy's first serious concern pertaining to immigration management. The law was meant to fix the emerging concerns and leading topics within the political and public discourses of the new migration flows - mainly from African countries such as Senegal, Morroco and Tunisia - and labour market-related issues. Particularly, the Law’s main regulations were aimed at stopping illegal migration flows, and the employing of illegal migrants (Abbondanza, 2017, p. 78). The way in which it accomplished the former was reactionary in how the law was implemented - primarily by increasing regulations at borders and re-finessing its asylum-related procedures. It also provided amnesty to over one-hundred thousand illegal migrants on the basis of the country's labour needs, as well as to combat lowfertility rates (Abbondanza, 2017, p. 78).

\section{Europeanization}

By the early 1990's, the Single European Act of 1986, intended to promote European integration, combined with the signing of the Schengen Agreement by the Northern European areas of the European Economic Community (ECC) pressured Italy to prove its capacity to the rest of Europe for managing migration flows (Abbondanza, 2017, p. 78). The Martelli Law (1990), of the sixth government of the Pentapartito led by Andreotti, regulated immigration more rigorously. The Martelli Law redefined legal definitions of statuses with subsequent procedures to follow such as asylum rights and procedures, the basis for denials, and residency requirements. Moreover, from a more formal legal perspective, it also structurally introduced the first official plan designed to match immigration and societal (labour) needs (Abbondanza, 2017, 
p. 79). Once again, the new law was accompanied by an amnesty program that regularized the migrants with which Italy's previous porous immigration policies had failed to deal with in an effective manner. This time, over 200,000 migrants saw their statuses regularized (Castellazzi, 2010, p. 113).

The Martelli Law, with a similar reactionary nature to its predecessor, the Foschi Law, solidified a formal and legal structure that permitted Italy to sign, yet not implement, the Schengen Agreement, along with the rest of the Northern European signees (Castellazzi, 2010, p. 113). The Law was criticized by scholars for many of the same reasons the Foschi Law was criticized; allegedly mismanaging immigration with part-regulation, part-Amnesty, while presenting no real, convincing plan other than a pilot project, which was to facilitate matching immigrants to Italy's labour needs. Despite the legislation, the extensive number of irregular migrants persisting throughout the 1990's proved that despite Italy's effort, its immigration laws and policies still required substantial improvement (Abbondanza, 2017, p. 79).

Internationally, several new developments were to prove significant in influencing migration flows into Italy. Most notably, the fall of the Soviet Union, uprisings in Poland, as well as turmoil in Albania. These changes to the political environment caused an influx of Polish and Albanian migrants throughout the 1990's. Italy reacted to this new wave of immigration by approaching the issue from a criminally inclined perspective, and passed the "Dini Decree" (Law No. 489) of 1995 (Bontempelli, 2009, p. 116).

By the summer of 1997, the Turco-Napolitano Law (1998) was finally signed and ready to be passed. Despite the aim to manage migration in a less transitory fashion, like its predecessors, the Law followed the same patterns of increased external controls and Amnesty. Again, regularizing hundreds of thousands of irregular workers (Italian Parliament, Law No. 40 
Art. 12.1 of 1998). In the following period leading in to the early 2000's, the Schengen Agreement, as well as the Amsterdam Treaty (1999), ultimately resulted in a common agreement of the signees that stricter border and immigration controls at strategic border points was necessary. Italy - being, geographically, one of those strategic border countries - saw the increasing criminalization of irregular immigration, and the link between crime and migrants within the public and political discourse became well established, aided by a few highly mediatised events that involved crimes committed by foreigners (Dal Lago, 2004 p. 27-8).

Italy's latest law and its procurements reflected the internal climate of the time; dichotomies between alarmism regarding criminal activity, national security issues and migrants, and domestic pull-factors for low-skilled labour shortages and low birth rates. In response, Italy adopted a more rigorous plan to deal with both perceived and actual migration-related issues. The country began detaining both immigrants and migrants and increased deportations of those perceived as threats. This arguably lessened the government's responsibility toward potential refugee claimants, as it simplified the process of identification and subsequent refusal or acceptance of refugees. Again, it also dealt with the internal irregularities via amnesty for irregular workers (250,000 along with the Dini Decree, and 217,000 through the TurcoNapolitano Law).

Due to the inadequacy of its models and policies, the multiple crisis that increased the ratio of irregular foreigners looking for refuge, and the continuous pressure of substantial numbers of irregular entries into its borders, Italy continued to have difficultly dealing with the migration patterns affecting it. Indeed, despite having regularized close to a million irregular workers in less than 25 years, one month after the amnesty of over 200,000 irregular workers (Through the Turco-Napolitano Law), it was estimated that the same amount of foreigners were 
still without a path to regularization within the country (Di Bello, 2000, 1.6). To that effect, foreigners in Italy experienced various degrees of political rejection while they looked for economic acceptance, clearly demonstrating a failing integration plan. In this environment, Italians remained complexly divided on issues of migration and immigration, trying to work with overarching migration policies in Europe while dealing with their own unique situation internally.

By the early 2000's, with existing migration patterns continuing, Italy boosted its use of the identification centres meant to deal quickly with incoming migrants while also increasing detentions and deportations (Abbondanza, 2017, p. 83). The replacement for the TurcoNapolitano Law, the Bossi-Fini Law of 2002, despite little difference to the model of its predecessors, further warranted the Italian Navy's involvement in enforcing the restricted access to its borders by sea, with an arguable side-intent of dealing with human trafficking (Abbondanza, 2017, p. 82; Italian Parliament, Law No. 189 Art. 33 of 2002). Internationally, growing concerns about Italy's dealing with vulnerable migrants, and most specifically, about the country being in violation of the principle of non-refoulement through its policies on deportations and detentions, led to charges of unconstitutionality by Amnesty International in 2006 (Amnesty International, 2006, p. 155-57). The charges were subsequently declared unfounded, thus inadmissible, by the Italian Constitutional Court itself in 2007 (Senate of the Italian Republic, judgment No. 22 of 2007).

There were other consequences to the gradual Europeanization of Italy, in terms of its adaptation of new policies affecting migration and immigration. The internal climate surrounding immigration, and the attitude that Italy has taken towards migrants, more affirmatively since the 9/11 attacks, have been influenced by the broader phenomenon of the global fear of terrorism, 
and the ever-growing popularity of national security. The ensuing period in Europe was characterized by a climate of fear, out of which were born new understandings of, and new legal frameworks dealing specifically with national threats and terrorism. As the definition of terrorism was broadened, and the mandated related actions were expanded, notably via the 2001 amended EU Counter-Terrorism Policy, a new, now broader spectrum of individuals could come under the scope of European anti-terrorism laws (Caiola, 2017, p. 411-414).

The framework for identifying potential terror threats was adopted and incorporated into the domestic legislations of various European nations, Italy inclusively, which was still very much completing its process of "Europeanization". Besides adhering to the EU's newly amended Counter-terrorism Policies, Italy was one of the nations which also adopted other lateral legislations and policies, all of which were specifically aimed at dealing with migration flows, immigration, and arguably, through a lens of criminality. It was during this time that asylum and immigration was increasingly criminalized both in the socio-political discourse, as well as within the political and legislative sphere. It was also during this period that, in 2007, the Italian government issued its special security package, which called for several augmented actions to be taken against foreigners perceived as threat to public security. As a result, and paired with the substantial migration flows to Italy in the early 2000 's, asylum seekers and other categories of migrants came under constant scrutiny by Italian authorities, and became the main subjects of new laws and policies, and legislative amendments aiming to ensure both national and public security. Italy further followed the global pattern of referring to spectacular events, such as highly mediatized murders committed by foreigners, to ferment fear of non-citizens and promote its public discourse of national and public security as a priority (Dal Lago, 2004, p. 27-8). 
The election of Italy's next Berlusconi government (2002), many scholars agree, was successful based on a growing public consensus concerning anti-immigration rhetoric. As Italy's politics moved from center-left to center-right, the Government embarked on a mission to externalize its control on immigration through the Libya Agreement (2004), and later through the Treaty of Lisbon (2008), which established a partial blockage of the southern borders, as well as the opening of Italian-run detention camps in Libya (Italian Parliament, Legislative Decree No. 241 of 2004). The successful stop-factor that represented Rome-Tripoli's joint venture against irregular migration and human trafficking attracted strong criticism from both internal, and nongovernmental organizations such as the Catholic Church, as well as from the international community represented by Amnesty International and The United Nations. The new relationship between Italy and Libya raised significant red flags considering the highly controversial political climate in Gadhafi's Libya at the time, a country that had not signed the 1951 Refugee Convention (Abbondanza, 2017, p. 84).

Despite the efforts, it was still a tumultuous period in the country as it officially declared in 2009, irregular entry the "crime of clandestine immigration" (Italian Parliament, Law No. 94 Art. 1, 15a of 2009). In Italy's context of mandatory prosecution laws, the latter both overwhelmed the country's legal bureaucracy and its courts, as well as putting vulnerable migrants at risk for harm (Abbondanza, 2017, p. 85). Following earlier patterns, Italy amnestied, for the sixth time, over 200,000 irregular workers, caregivers, as well as other types of immigrants (Italian Parliament, Law No. 102 of 2009). This similar pattern of stern external policies versus lax internal ones occurred, historically, regardless of the type of government in power; however, as noted later in the paper the current government is on a path to keeping consistency between exterior and interior policies relating to migrants and immigrants. 


\section{The Arab Springs}

The ensuing phase in Italy's immigration and asylum policy was unavoidably and crucially affected by the Arab Spring of 2011 along with neoliberal reforms that were increasing poverty in the Global South. The transnational effects of the event continue to spread quickly across the globe, and arguably, even more-so in Europe. Italy has been and continues to be drastically affected by the aftermath and the humanitarian crisis that followed. The massive protests, wars and military interventions led to Italy's largest influx of sea arrivals, most notably in the years 2014,2015 and $2016^{2}$. Meanwhile, many observers as well as the media have deemed this particular period the Mediterranean migration crisis ${ }^{3}$.

As the political situation worsened in the Middle East and significantly impacted Europe, EU nations became more and more divided on the topic of migration management. This was especially observable with the case of Italy as the country's government grew increasingly dissatisfied of the EU's procedures and protocols for dealing with what it regarded as a fullblown humanitarian emergency. This, combined with the international military interventions of Libya in 2011, leaving it as a war zone with no government, and the subsequent crumbling of its agreement with Italy, again flooded Italy with significant numbers of persons crossing and entering its southern and lateral borders irregularly (Lombardi, 2011, p.31).

While all of Europe has been affected by the Arab Springs and by the war in Syria, amongst other events of the 2010's, the ratio of migrants of the ensuing exoduses entering Italy

\footnotetext{
${ }^{2}$ Numbers of sea arrivals to Italy for years 2014, 2015, and 2016 were 170,100, 153,842, and 181,436 respectively (United Nations High Commissioner for Refugees, 2019).

${ }^{3}$ A simple internet search for the years 2014 to 2016 shows countless media, as well as journal articles and reports referring to this period as the migration crisis of the Mediterranean due to the precipitous number of sea-borne migrants.
} 
was genuinely substantial (Abbondanza, 2017, p. 85). As noted earlier, in 2012, concerns were raised that Italy was dealing with its migration flows in an anti-humanitarian fashion. In fact, the European Court of Human Rights condemned Italy that same year for forced repatriations, as well as for its violation of the non-refoulement right of thousands of migrants to Libya and Somalia (Amnesty International, 2012). As a stop-gap measure, once again Italy followed its earlier pattern of governing migration by issuing its last amnesty for irregular immigrants, regularizing and documenting this time only about 23,000 persons (2012) (Italian Parliament, Legislative Decree No. 109 of 2012).

\section{The Mare Nostrum}

Italy's migration policies became increasingly influenced by exogenous factors as the humanitarian crises in the Middle East persisted and worsened. The 2013 sinking of a Libyan ship off the coast of Lampedusa, which resulted in close to 400 deaths, was the tragedy that initiated the beginning of the next policy chapter for Italy (Davies, 2013). Italy continued with the externalization of its migration regulations as it launched the mission of the Mare Nostrum, which was a clear manifestation of the country's dichotomic migration agenda and polices. Through both a humanitarian and a military dimension, the Mare Nostrum, a navy ship and improvised rescue-ship, effectively represented both a pull-factor for migrants seeking to depart from the coast of Libya, as well as the clear manifestation of Italy's strict regulation of its borders. The conditions on the ship for the migrants it rescued at sea were questionable, however, through its commitment to saving lives in the Mediterranean, along with "countering" human trafficking at sea, the results of the annual bilan for the following year attests that the mission was successful at achieving both. The flow of migrants towards Italy in the year of 2014 
was the largest in the world, and the Mare Nostrum rescued 170,000 migrants at sea who would have otherwise possibly died (Abbondanza, 2017, p. 86). Despite these efforts, the Mare Nostrum mission was criticized for both its military as well for its humanitarian aspect ${ }^{4}$.

A clear issue that arose with the mission was the lack of supporting systems to further advance and do justice to its own efforts. The weak procedural dimension of Italy's immigration policy meant that those who were not immediately returned to their origin countries were forced upon a difficult path to asylum, as well as ultimately, a lack of integrating support by the government (Nallu, 2019). Beyond that, Italy was already "fed up" with the lack of help from the European Union, and while it portrayed the mission as part humanitarian, woven into that mission was Italy's way of making sure many of the migrants rescued would not stay in Italy, or could not be deported back to Italy under the Dublin Agreement (Nallu, 2019). To do so, Italian authorities purposefully did not stamp or register many of the arrivals of the migrants; those were mainly left to themselves and to continue their journeys to other countries of Europe. This situation and the sheer number of migrants rescued by the ship, registered or otherwise at Italy's borders, only added to the already precarious socio-political situation in Italy, as well further negatively influenced Italy's relations with the rest of the European Union.

In the end, a mix of factors put an end to the mission, after only a short period in operation. Italy's Minister of Interior Angelino Alfano was the first to announce that Italy wished

\footnotetext{
${ }^{4}$ Because of the large increase of migrants attempting to cross the Mediterranean in 2014, the second (and last) year of operation of the Mare Nostrum, some observers of the phenomenon have questioned whether the operation might have acted as a pull-factor for migrants, who would have felt they had better chances at succeed in reaching Europe knowing they would most likely be rescued by the Mare Nostrum. Observers holding this view typically argue that the majority of migrants rescued by the ship were economic migrants or even terrorists from Muslim countries such as Syria. The proponents of the other side of the debate claimed that the surge in numbers of migrants in 2014 were attributable, rather, to upheavals in countries at war such as Syria, Eritrea, and Libya, pointing out that those were the countries of origin most common amongst the migrants. Consequently, they point out that Italy, with its superficial identification processes may have returned legitimate refugees (AEDH, 2017; Davies, 2014).
} 
to end the mission once the EU-operated border control mission, Frontex's Triton, started in November of 2014 (Amnesty International, 2014). This time, operating just off the coast of Libya, the main mission of Triton was to be strictly military in nature; human rights organizations feared that the limitations of the mission would result in many lives lost at sea (Amnesty International, 2014). Meanwhile, it is clear now that it was too late for the Mare Nostrum: the rise of the right, anti-migrant sentiments in Italy had already decided of its fate. Today, Frontex's Triton mission continues to be cause for debate between Italy and the European Union as both parties continue to push different agendas. Italy aims at halting and returning migrants, while EU and Frontex-operated Triton tries to follow international refugee laws, which dictate that the responsibility to process refugee claims falls on the closest country available after their rescue - Italy (Abbondanza, 2017, p. 87). 


\section{Part 2: Laws and Policies in Practice}

Substantive changes to immigration policy and law in Italy were provided by the 2002 Bossi-Fini Law. However, the Consolidated Immigration Act (Testo unico delle disposizioni concerenti la disciplina dell'immigrazione e norme sulla condizione dello straniero), despite numerous amendments over the years, remains one of the main relevant legislation to immigration detention, asylum procedures, and reception directives today (Global Detention Project, 2018, p. 4). The grounds for detention of non-citizens are still established by the TurcoNapolitano Law of 1998, in which the mechanisms for administrative expulsion orders, visa overstays, illegal entry, and border control evasion, are provided (Global Detention Project, 2018 , p. 4). The Law defines the protocol to follow in cases where expulsion is requested by authorities. For example, that a "validation hearing" in front of a judge must occur, and that temporary detention shall be communicated to the judge by the police. The law is - in theory - in accordance with the international law of non-refoulement, by stating that direct and immediate expulsion or return of individuals is unlawful; in practice, however, it is often not respected.

In order to analyze Italy's migration and asylum laws and policies, it is imperative to examine how the former are put in practice. Initially, three aspects of Italian law are of particular interest to this analysis: first, the fundamental rights of undocumented migrants that are explicitly affirmed within Italian legislation's Immigration Act, which states that migrants, or non-citizens, regardless of their legal status or lack there-of, must have their rights recognised by the state (Italian Parliament, Article 2(1) of the Immigration Act). Second, it is affirmed in the Italian Constitution that the rights of foreigners are regulated by Italian laws and in accordance with International standards and treaties, within which the right to asylum is provided (Italian Parliament, Article 10 of the Italian Constitution). Third, the Constitution provides that personal 
liberty of all individuals is inviolable unless judicially and lawfully proceeded against and acted upon; as I will discuss below, however, the personal liberty of migrants is often not respected (Italian Parliament, Article 13 of the Immigration Act).

\section{Grounds for Detention}

Migrants may be detained if they are not eligible for the status of refugees, as defined by the Geneva Refugee Convention. Migrants may also be considered a danger to public order and security and subsequently issued an order of expulsion by the state if they are suspected to be related to organized crime, suspected of having committed crimes of war or terrorism, or if they pose a risk of absconding (Italian Council of Refugees \& Association for Legal Studies on Immigration, 2018). Children and pregnant women or women that gave birth less than six months prior cannot be returned or expelled from the country, and unaccompanied minors shall not be detained in dedicated detention centers, unless they are along with their family members upon request of the former, and under the authorization of a judge (Italian Parliament, Decree 142/205 Article 19(4) of 2016). However, as discussed later in my paper, in practice this is a very different situation.

The limited scope of "vulnerability" as understood by Italian law regarding migrants is a concern. While children and pregnant women are without a doubt, vulnerable migrants, other individuals, such as those with physical or mental disabilities, women in general, LGBTQ individuals, as well as younger individuals and seniors, are not covered by the vulnerability scope and may therefore be detained. Besides, organizations such as Human Rights Watch report that are unaccompanied minors detained in hotspots in Italy against the country's own laws; they, along with other vulnerable migrants, report physical and sexual abuse from both guards 
and other detainees (Human Rights Watch, 2016). Thus, in practice, Italy does not follow its own migration policies on the detention of vulnerable migrants, and this results in their wellbeing put at risk and their basic rights being violated

\section{Detentions: Procedural Violations}

Detained migrants often face other violations of their rights in relation to procedural guarantees and their detention. For example, both the validation and extension hearings have been the subjects of criticism by NGO's and other such groups, claiming that the judges involved often have very little knowledge of the particulars of Italian Immigration Law (Global Detention Project, 2018, p. 7). Similarly, the competency of the public defenders assigned to represent detainees in court is also questioned, and the near absence of interpreters significantly disadvantages migrants' representation in front of the judge (Monitoring Center on Judicial Control of Migrants’ Removal, 2016). Ultimately, decisions of subsequent detentions or expulsions often rely on only superficial judicial reasoning and are ultimately the result of poor systematic protocols (Global Detention Project, 2018, p. 7). All of the above compound the situation to create delays in the hearings of migrants. These delays are not formally recognized and thus, they are unofficially tolerated despite laws clearly setting the maximum detention lengths between 30 to 90 days for assessment and pre-removal purposes, and 12 months for asylum seekers (Italian Parliament, Consolidated Immigration Act Article 1(5); Decree 142/2015, Article 6.8 of 2016).

\section{Alternatives to Detention}

In 2011, alternatives to detention procedures were introduced as part of the amendment of the Consolidate Immigration Act, reversing the prior laws in accordance with the EU Returns 
Directives (Global Detention Project, 2018, p. 8). Officials then had the option to order three different types of non-custodial measures in cases for which detention may be ordered; the relinquishing of a passport or equivalent official identification documents, the obligation to reside at a previously identified location, and reporting obligations (Global Detention Project, 2018, p. 8).

There are, nonetheless, issues with the accessibility of those alternative measures, as well as concerns as to their actual usage. First, these measures are only available to documented individuals. Second, evidence shows that in cities where detention centers and hotspots are present, very little usage of alternative measures are ordered by judges; clearly demonstrating that when detention is available, it is chosen as a procedure over alternative measures (Monitoring Center on Judicial Control of Migrants' Removal, 2016). Moreover, where alternative measures are used, data shows that the most common combination of measure orders are the surrendering of a passport or equivalent documents, and an obligation to report. This highlights government officials' will to exercise considerable control over migrants' whereabouts within the country (Monitoring Center on Judicial Control of Migrants' Removal, 2016).

\section{Hotspots}

Another area of concern consists of the multiple "hotspots" that are located at the most popular points of entry into Italy - for example Lampedusa. Ideally, these hot spots are supposed to "inject greater order into migration management by ensuring that all of those who arrive are identified, registered, and properly processed" (European Parliament, 2016, p. 8). In theory, these centers are designed to facilitate the processes pertaining to the EU's program of re- 
location of refugees, as well as to speed-up the return of ineligible, and economic migrants (Global Detention Project, 2018, p. 8). However, hotspots are not regulated by any specific laws; rather, they operate under a close-door policy, lacking transparency, and are only regulated at a policy level developed by the Interior Ministry (European Parliament, 2016, p. 8-9). The policy pertaining to hot spots was drafted with the help of the European Commission, Frontex, the Asylum Support Office, the UNHCR, and the IOM (Global Detention Project, 2018, p.9). Lack of Regulations and Transparency - Hotspots and the Role of Authorities

In Italy, agreements between the police and other comparable authorities of other countries, as well as many internal directives on dealing with migrants, do not require prior approval from Parliament. This has resulted in a loophole through which Italy is accused of exercising quasi-legislative power without the applicable legislative accountability (Global Detention Project, 2018, p. 12; European Parliament, 2016, p. 8). These agreements are often voluntarily hidden from the public and from the international community, and only come to light accidentally (Global Detention Project, 2018, p.9). This also creates a space for Italian authorities, and ultimately Italy, to run their own "on-the-side" agendas as far as migration management. One example of such agreement was a 2016 "memorandum of understanding" between Italy and Sudan's police. This became known to the public and the international community when the above-mentioned arrangement permitted the coercive return of close to 50 potential Sudanese refugees to their country of origin. Their return required substantial transnational cooperation between officials since the migrants had to be transported both by sea and by air from ports to airports, in order to finally reach Sudan (Association for Juridical Studies on Immigration, 2016). Amnesty International, after finding out about the event, declared the forceful return of the migrants unlegislated and against Italy's own policies (Amnesty International, 2016, p. 51). 


\section{Identification Practices in Hotspots}

One of the human rights-related issues that arises from the lack of legal regulation of hotspots in Italy is the mandatory fingerprinting. In practice, migrants are not allowed to leave the premises of hotspots until they have been identified and fingerprinted for their registration, a practice that should not take more than 48 hours as per the Consolidated Immigration Act (Global Detention Project, 2018, p. 9). Nonetheless, reports tend to show that whether due to slowly moving procedures because of the number of arrivals, or due to refusal on the part of migrants, the allowed period of administrative retention is often surpassed by many weeks (Amnesty International, 2016, p. 17). On the other hand, reports and data shows that fingerprinting is increasing every year, and human rights organizations report that abusive and coercive force - torture techniques such as food and sleep deprivation - are often used in order to obtain the fingerprints from migrants in hotspots (Amnesty International, 2016, p. 17).

According to observers, Italian officials even transfer migrants apprehended in other regions where hotspots are not present to hotspots for the purposes of "identification". However, hotspots are only supposed to be utilized with migrants apprehended within their geographic zones. Reports claim that the migrants transferred to hotspots are often already identified and registered, which in theory defeats the purpose of their transfer, unless the purpose is otherwise (Quadroni \& Luppi, 2016). This adds to the significant concerns with regards to the adequacy of identification measures of migrants, with reporters claiming that migrants are evaluated and identified on the basis of a short, superficial interview consisting of only a few simple questions such as pertaining to their reason for being in Italy. For example, migrants are asked right away to choose between five options as far as the reason for their presence in the country: (1) for occupation, (2) to join relatives, (3) escaping poverty, (4) asylum, (5) other reasons (Global Detention Project, 2018, p. 10). Obviously, the only correct answer is asylum, however, the 
simplistic format of the questionnaire may be confusing to migrants. This could result in the potentially unlawful expulsion of vulnerable migrants and potential refugees, putting their lives at risk and violating their right to asylum. Overall, the procedures conducted by officials assigned to hotspots are highly questionable, and hotspots in Italy are claimed to have undertaken the unofficial role of detention centers ${ }^{5}$.

The treatment of migrants while in detention is also questioned, as numerous reports of mistreatment inside Italy's de facto detention centers continue to surface. As already noted, the procedure that appears to be particularly problematic is mandatory fingerprinting. Amnesty International, amongst other organizations, has long claimed that the procedure often turns violent and abusive against migrants who refuse to cooperate with Italian authorities. Often, the refusal is due to the desire of the immigrants to continue their journeys to other countries rather than having to seek asylum in Italy (Amnesty International, 2016, p. 17). Detained migrants have reported being beaten with batons and electrocuted, sexually abused and humiliated, as well as given no food or water by the Italian police ${ }^{6}$.

\section{Corruption in Hotspots and other immigration centers that results in mistreatments}

Besides reports of human rights violations in immigration centers, the privately-offered services subcontracted by Italy for the management and care of immigration centers and

\footnotetext{
${ }^{5}$ Complaints to NGO's about migrants being arbitrarily and illegally detained started within the first few months of Italy's hotspot system. As discussed in this paper, issues arise from the fact that hotspots are not regulated at the legal level in Italy, in which case reports of violations of individuals' liberty become difficult to defend at the juridical level. Moreover, while technically the time of detention should be equal to the time needed to identify migrants, reports indicate that this is not always respected and that migrants are sometimes held for longer periods of time. Here again, the situation is difficult to analyze on a legal level because of the lack of regulations of the concerned procedures and timeframes (Caprioglio, Ferri, \& Gennari 2018).

${ }^{6}$ Reports of "electricity rooms" are common, despite the police denying the accusations. Amnesty International reports incidents similar or related to the ones described above in police stations in Sicily, Puglia, in the hotspots of Taranto, Lampedusa, Pozzallo, and other police stations in Bari, Cagliari, Catania, Foggia, Savona and a reception center in Ancona (Amnesty International, 2016).
} 
migrants result in corruption, mismanagement and mistreatments (Martone, 2016). Immigration centers in Italy are regulated at a policy level only (Italian Interior Ministry, 2013). The Ministry in turn contracts out services to be given and provided to and within immigration centers. Several different companies, cooperatives, associations, as well as both non-profit and for-profit organizations are involved resulting in irregular management and servicing (Global Detention Project, 2018, p. 13). This results in an environment that is prone to corruption, which ultimately affects the migrants who then receive inadequate healthcare, lack of food, abusive physical treatment, and even un-warranted delays, as well as the inadequate representation and assistance relating to their legal immigration procedures (Global Detention Project, 2018, p. 13). Several of the organizations and associations in charge of managing or providing services to the centers have been investigated for fraud, corruption, or other criminal behaviours ${ }^{7}$.

\section{Deportations}

With regard to the deportation processes, Italy has discriminatory and racist practices through which it targets certain nationalities - for example by using quotas to establish numbers of specific nationalities that are to be deported. There are reports of seats in planes that are "reserved" for deportations, and that officials such as the police are encouraged to conduct strategic raids, with the intent of arresting specific nationalities (Global Detention Project, 2018, p. 11). Relying upon the fact that overstay is criminalized, police target, track down and arrest certain nationalities for the purpose of deportation. This is not only discriminative, but may also

\footnotetext{
${ }^{7}$ See Martone, V. (2016) for a report on the "Mondo di Mezzo" inquiry of 2014, in Rome Italy, which unveiled a modern criminal organization named the "Mafia Capitale", and how it functioned as a "large network of social cooperatives that penetrates [...] public administration and public-private companies to get tenders in sectors linked to the welfare state [...] [and thereby] make important inroads into the management of migrant reception centres in Rome".
} 
further violate the non-refoulement regulations and put potential refugees and vulnerable migrants' at risk by returning them to countries in which they may be persecuted.

\section{Working with Repressive Governments}

As mentioned earlier, the current political atmosphere in Libya is preventing the formalization of migration-related agreements with Italy, yet the Interior Ministry of Italy continues to stress the importance of the cooperation between their two countries on this subject (Global Detention Project, 2018, p. 12). Relevant to this situation is that Italy's migrants are mainly seaborne, and the majority of them depart from Libya. For example, in 2016, eighty-nine percent of migrants arriving to Italian shores had embarked from the Libyan coats (United Nations High Commissioner for Refugees, 2016). Thus, since 2009, it is undeniable that Italy continues to work closely with Libya - and with Libyan Coast Guard - with the goal of stemming migration flows from the sea route that separates both countries. The collaboration has indeed been fruitful, with Italy claiming as of 2017 a dramatic reduction in arrivals that year, but again, international organizations accuse Italy of violating migrants' human rights because of this relationship with Libya, as well as the principle of non-refoulement through their efforts (Barigazzi, 2017).

\section{Lack of Integration Framework}

Being forced out of formal settlements (because of strategic raids by Italian police).with no where to go, and with little to no resources, many refugees end up in informal settlements scattered across the country, or simply homeless (Doctors Without Borders, 2018, p. 1). Many international organizations and civil groups monitoring the situation claim that the conditions in 
both formal and informal settlements is as deplorable as the one in hotspots, and other similar reception/ holding/ detention centers for migrants in Italy (Doctors Without Borders, 2018, p. 2). The migrants' entitlement to medical care and other support services are often dependent upon a fixed address, and thus, many of their rights as temporary residents, and asylum claimants are systematically denied (Doctors Without Borders, 2018, p. 2). International organizations denounce Italy for ignoring of these sites, and the situation of their residents and occupants, and accuse the country's leaders of using the number of arrivals to its borders to justify human rights violations (Doctors Without Borders, 2018, p. 2-3). 


\section{Part 3: Recent Developments}

\section{The Salvini Government and the Rise of Anti-Migrant Sentiment}

Within political and state systems, charismatic leaders can have significant impact. As seen in other countries like Canada and the United States, Italy is no different. In this case, Matteo Salvini has gained significant impact and influence over the political situation in Italy. He entered the political sphere by joining the then Northern League as a teenager in the 1990's (Sunday Independent, 2018). The Party, originally a federalist-separatist movement calling for the separation of the Northern part of Italy, was considered historically ordinary and by the time Salvini became secretary, in 2013, the Northern League was nearly destitute in the face of one of the biggest scandal in the history of the party, which involved the embezzlement of over 40 millions euros by the treasurer and the then-leader Umberto Bossi (Stille, 2018). In 2014, Salvini took over the reins, and brought changes to both the name, as well as to the ideological positioning of the party, leaving "Northern" out, and channeling re-focused nationalist ideologies (Sunday Independent, 2018).

In the 2018 elections, the League and the Five Star Movement, led by comedian Beppe Grillo, ran as competitors. Both parties presented political positions that they claimed were neither left or right and this allowed them to gain interest and support from a wide range of voters. Despite their differences, they did have some points in common, particularly their critical opinion of the Italian establishment of the time, and of the EU (Stille, 2018). Ultimately, the storm of events surrounding the migrant crisis that was still unfolding during the time of the elections helped Salvini establish and support his claims that Italy was in need of a government that started "putting Italians first." 
As noted earlier, as Libya's government crumbled and chaos ensued, never-seen-before numbers of migrants began to literally wash up on Italy's shores during the years 2014, 2015, 2016, and although declining still this influx certainly continued into 2018. Through these events, Salvini seemed able to validate his claims that Italy had clear antagonists: migrants, the EU, and by extension Italy's ineffective government at the time (Stille, 2018). After the party's successful elections of 2018, the League formally identified the new enemies of its now Nationalist Party. Seemingly against all logic, Salvini turned a separatist movement into a nationalist one, increasing in popularity day by day and garnering Italians from all regions of the country (Stille, 2018). After taking power, the clear rhetoric of the party was that migrants were now the new enemy number one of the state.

Today, the League continues to embody, nonetheless, the Bossi-coined neologism of "celodurismo" - the Italian version of Latin American-style, ultimate sexism and machismo through its harsh attitude towards migrants. The connotations that the term conveys are extremely worrisome and not at all politically acceptable; but nowhere near as caustic as the blatant anti-immigrant racist language that Salvini frequently uses. As the country's oldest political party, the League is now more defiantly xenophobic than ever, and its popularity is at a peak - at least amongst voters (Sunday Independent, 2018). As a result, Italians have widely supported Salvini in his mission to defend Italy's coast lines, and by extension his fight against migrants, international human rights organizations, and the rest of the EU.

As noted earlier, in the past, Italy opened its borders to asylum seekers and sustained a relatively good standing concerning human rights of migrants with entities such as the EU and the United Nations. However, within the first few weeks in power, Salvini effectively barred rescue ships full of vulnerable migrants - notably the Aquarius and the Lifeline - from entry into 
its ports, and forced them to continue their journeys to other European countries (Sunday Independent, 2018). Before and after his election to power, Salvini made numerous racist, xenophobic, and outright frightening comments about migrants and non-citizens living in the country, regardless of if they were there legally or illegally. Through his use of social media and in televised interviews he promotes the mediatization - as in, he purposely mentions certain events on his very active social media accounts, as well as uses every opportunity, such as conferences, to discuss certain events that support his anti-migrant rhetoric - of certain crimes involving non-citizens. He is also publicly vocal and explicitly critical of how, he claims, the rest of the EU treats Italy as their "refugee camp of Europe" (Jones, 2018). As this situation continues to unfold and his political power continues to influence the public sphere, many onlookers are becoming increasingly worried about the potential repercussion that Salvini's racist discourse will have on Italy and the rest of Europe in general. It has been pointed out, for example, that the language he uses echoes the language used by pre-war Nazis (Strickland, 2018).

Despite the League appearing to echo Bossi’s “celodurismo” attitude, Salvini’s public image has also been, at times, perceived as a suppler, more friendly character (Stille, 2018). Observers have often pointed out that Salvini has taken advantage of numerous occasions to make references to things such as family, goodness and generosity in order to be more relatable (Stille, 2018). Showing great media savviness, Salvini swiftly manages controversial situations, and makes impressive come-backs from his own inflammatory comments, which in the end help his popularity. For example, in 2014, after protesters surrounded Salvini's car while he visited the informal gypsy settlements outside of Rome, which he had previously threatened to "bulldoze down", the driver sped-up to avoid the potentially dangerous situation. One protester 
could have been hit if it was not for Salvini apparently ordering the driver to slow down. Once the story went public, Salvini was effectively portrayed as a kind-hearted but hard-headed man, and his gain in popularity because of this event and how it was mediatized was almost instantly noticeable through social media (Stille, 2018).

\section{The Salvini Safety Decree}

Significant recent developments in Italy include Salvini’s “security package” Decree (2018) that, not surprisingly, exemplify and reflects his personal views on what should be the suitable management plan for migration and immigration in Italy. The Safety Decree - or, as it has been popularly called, The Salvini Decree - was drafted by the Minister of Interior, and consists in 40 articles divided in 4 separate categories. The majority of them introduce new provisions, and depict an alarming focus on matters of immigration (Mondaq Business Briefing, 17 April 2019).

Some of the most important provisions include amendments to the Italian Consolidated Law on legal expenses through the introduction of Article 130b. This establishes that the State will no longer pay for the legal defense of migrants who's case resulted in an appeal being dismissed for inadmissibility, amendments to the right to political asylum, and expulsion of foreigners, and an extended list of grounds for the withdrawal of refugee resident permits to include criminal offences such as sexual violence, drug-related offenses, as well violence towards representatives of public authorities (Mondaq Business Briefing, 17 April 2019). Consequently, despite the legal procedures concerning migrants being already highly criticized by NGO's and other observers, and despite Italy's government consistently admitting that their legal system is overrun by immigration-related cases, migrants who have already been 
disadvantaged by the formerly-mentioned context will now have little to no recourse if the inadequate proceedings in their immigration cases results in a finding of inadmissibility.

Furthermore, the Decree abolished and effectively revoked all humanitarian residence permits - the most widely used in Italy - and replaced them by temporary permits only (Mondaq Business Briefing, 17 April 2019). The Decree also provides for a simplified legal procedure, installing all jurisdiction in the Court itself, which will be required to conduct only a summary proceeding for all appeals to refusals and withdrawals of temporary residence permits (Mondaq Business Briefing, 17 April 2019). All appeals to Court decisions will need to be submitted within 30 days of the notification of withdrawal or denial, for migrants residing in the country (Mondaq Business Briefing, 17 April 2019). This significantly disadvantages vulnerable migrants by first, revoking their right to residency for humanitarian reasons in Italy, and second, by further cutting back on the required analysis and expected consideration each case should get in Court. Furthermore, it complicates the procedure for migrants wanting to appeal the decisions made in their cases since it shortens the deadline for an appeal. With very little resources to begin with, most migrants will have difficulty finding the funds and the counselling services necessary to file for a proper appeal within the new time-limits of 30 days. Finally, the Decree has also extended the time-limit period of provisory detention of migrants in detention centers from 90 to 180 days, and now provides stricter requirements for the already controversial procedure of identification of migrants (Mondaq Business Briefing, 17 April 2019). 


\section{Discussion and Findings}

Based on my research, Italy has historically dealt with migration and immigration in a dichotomous, contradictory manner. It responded to irregular migration nearly the same way, despite the different reasons for migration, and despite passing new laws and regardless of the position of its government. Italy reacted to different push and pull factors over the years, both internally and externally, by amending its legislation and policies; however, each time, the overall result was the same - increased regulations and substantial amnesties. In total, about 1.7 million migrants, mostly irregular workers, were regularized (Abbondanza, 2017, p. 89). This dichotomy can also be observed in many of the specific undertakings of the Italian Government over the years. For example, Italy's agreements with Libya - a dictatorship that has yet to ratify the 1951 Convention on Refugees - on the one hand, while on the other hand funding the Mare Nostrum, a humanitarian military mission that saved nearly 200,000 lives at sea in one year.

Moreover, politically and legislatively speaking, Italy has, for the most part, taken an eclectic rather than wholistic approach to migration policy - meaning, rather than having a plan, Italy persists in making its migration policies "on the fly", reacting to mediatized events or external factors rather than by taking a more comprehensive approach to policy making. This is fueled in part by minority-ruling parties with drastically varying agendas, resulting in disagreements, contradictions and delays in the drafting and passing of laws - Italy's governments are usually not in power long enough to be able to comprehensively reform laws and policies. One of various examples of this governing pattern happened in 2007, when the Minister of Interior issued a special "security package" of reforms in response to recent crimes committed by foreigners, that amongst other things, authorized Italian authorities to remove EU citizens that had committed the crime of "clandestine immigration". The Refounded 
Communists, however, negated the reforms, which resulted in a delay of nearly 2 years before its enforcement (Law No. 102 of 2009) (Glynn, 2016, p. 166).

In 2009, when it finally passed, Berlusconi's "security package" criminalized irregular entry into Italy, designating it an aggravating factor under Italian criminal law, punishable with fines and provisory detention until expulsion (Italian Parliament, Law No. 125 Art. 1(g) of 2009). Then, in 2014, Parliament mandated the government to de-criminalize irregular entry and undocumented stay in Italy but ultimately, the drafting and amending, yet again, exceeded the limit period of 18 months, and the revised law was never enacted (Global Detention Project, 2018, p. 10). All in all, with 62 governments since the Second World War and counting, Italy's governments have been known to be particularly fragile with short political lives. Undeniably, each time the government shifts, Italy's capacity to adequately manage migration and asylum policies is affected (Glynn, 2016, p. 166). Thus, over the years, Italy's political sphere has become increasingly unstable, and besides affecting how it deals with migration, this also affects other, closely related areas such as the country's economy.

Instability in the Middle East and other parts of Africa has also significantly affected migration policies in Italy. The relationship between Italy and the rest of the European Union, as well as with many international organizations such as the UN, was particularly affected by this turmoil. Despite Italy being, historically, a notable supporter of, and contributor to, the United Nations, the relationship has started to crumble under the pressure that Italy experiences due to the vast number of migrants flowing into the country. From Italy's perspective, the UN is not doing enough to alleviate the pressure that migration flows are exercising on its political, legal, and economic systems. From the UN's perspective, Italy's action concerning migrants is violating human rights on various levels, and numbers should not be an excuse. These conflicting 
views clashed recently, as Italy threatened to fine migrant rescuers if they then entered Italian borders, as well as to revoke and suspend the licences of NGO's and other boats that rescued migrants in Italian territory (United Nations, 2019). Soon after, in June of 2019, the German captain of a ship rescuing migrants at sea was arrested for allegedly ramming an Italian police boat blocking its way into the harbour of Lampedusa (Camilli \& D'Emilio, 2019). The incident happened after Italy denied the rescue ship entry into the port until other European countries agreed to take the migrants (Camilli \& D'Emilio, 2019).

The sporadic periods of improvement in Italy's asylum system throughout the early 2000's, largely attributable to Italy's gradual Europeanization, were of minor impact. In 2008, The left-wing Prodi government attempted to legislate the introduction of the European Commission's Qualifications Directive and Procedure, which formed part of the EU's Common European Asylum System (CEAS) (Glynn, 2016, p. 179). This was highly significant for asylum seekers in Italy at the time, since these directives allowed those who were not eligible in Italy as refugees but wished to continue their journey, the ability to access secondary care and services such as shelter and health care in the meantime (Glynn, 2016, p. 179). Thus, via the EU's directives on qualifications that were adopted by Italy, a broader spectrum of migrants were at least temporarily supported and protected. Even then, Italy was still challenged by a constant high number of arrivals and a shortage of space, accommodation and resource professionals to deal with the influx. Over all, the directives were only useful to a certain extent, and did not, unfortunately, make a significant difference for asylum seekers in Italy (Glynn, 2016, p. 179).

For decades now, and to this moment, migrants prefer not to remain in the country, and most of them continue their journeys to other European nations. As explained by the UN and the High Commissioner of the Council of Europe, Italy lacks a strong and effective integration 
framework for immigrants. Besides the controversy surrounding Italy's migration policies and laws in practice, and the treatment of migrants with its high unemployment rate, poor social security system, and rampant discrimination against foreigners and immigrants, Italy has little to offer in terms of opportunities to refugees and newcomers alike (Glynn, 2016, p. 179).

Salvini is now effectively negating migrants' access the humanitarian protection they desperately need, which is equivalent to violating their constitutional rights as refugees and asylum seekers (United Nations, 2019). He has stated that the goal of the new Safety Decree is to increase public security by facilitating the legal process of refusal of residency or citizenship, as well as of expulsion of "fake refugees, criminals, terrorists", and to decrease state spending on what he considers "exaggerated migration" (Salvini cited in Giuffrida, 2018). Critics, however, point out that the Decree - besides violating migrants' rights - could also have adverse effects on Italy's public safety and on its legal system, as well as affect its capacity to properly manage migration. By abolishing the humanitarian residency permits of thousands of migrants, many of them living in both formal and informal settlements, Italy will make vulnerable individuals all the more helpless. Since their funds and resources are negligible, many migrants will most likely become and/or remain irregular in status. The marginalization they will suffer through the new decree and its implementation will undoubtedly have significant negative repercussions on Italian society as most will seek to find informal means to secure accommodation and work (Iacobini de Fazio, 2019). Data shows that while crime rates have decreased in Italy over the past decade, the percentage of crimes committed by non-citizens is far higher for irregular migrants, since they lack legal work opportunities and are easily hired to do illegal work such as selling drugs or counterfeit products on the street (Iacobini de Fazio, 2019; Still, 2018). 
The Salvini Decree will undoubtedly continue to feed into many Italians' misconceptions about migrants, crime, and safety. As scholars point out, the mediatization of controversial subjects related to, and inflammatory comments about migration flows into Italy, has resulted in Italians having an exaggerated perception of the actual percentage that immigrants represent of the Italian population (Stille, 2018). While it is accurate to say that migrants' arrivals has increased over the past years, Italians believe the population of immigrants to be about twenty percent higher than what it actually is (Boeri cited in Fonte \& Balmer, 2018). Introducing a decree of "safety" with nearly entirely immigration-related provisions and amendments effectively reinforces the problematic and erroneous public perception of migrants as dangerous, and even terrorists, and of the wrongly-assumed correlation between migrants, immigrants and crime.

Consequently, by stripping current holders of legal permits to stay in the country, and by making the path to legal residency in Italy more difficult, the government will effectively increase the number of irregular migrants within its borders, and by extension, may push more irregular migrants to commit crimes as they are left in desperate situations of work and accommodation. Ultimately, this defeats the "safety" purpose of the decree, and the number of irregular migrants will increase. In the past, Italy had dealt with irregular migrants that its system was not able to manage by giving massive amnesties, but this time it is highly unlikely to happen - in fact, the exact opposite is about to happen as Italy begins stripping legally residing noncitizens of their statuses. All in all, it is unclear, considering Italy's legal system and inadequate migration management, how the government will deal with the thousands of individuals that are about to become irregularized, homeless, and ultimately desperate. 


\section{Conclusions}

It is possible to observe four distinctive phases in the evolution of Italy's migration policies, all of which are marked by at least four broader categories of influencing factors. The first phase encompasses from about 1880, up to the 1970's, and consists of Italy's emigration period (Abbondanza, 2017, p. 89). This period was influenced by Italy's historical context - its relatively short colonial contextualized external pull factors prone to emigration, such as higher economic development and opportunity in other European countries. Reflectively, no real legal framework existed concerning immigration policy. The second phase was characterized by the country's transition to its immigration period, and pertains more specifically to the 1970s until 1990, which was influenced mainly by external factors such as the global oil crisis that prompted migration flows across Europe. The third phase was marked by Italy's Europeanization and the early beginning of the European Union, and was influenced by various external and internal factors such as the Schengen Agreement and the subsequent will of many signatories to strategically control certain borders across Europe. Turmoil in Albania and Poland, the fall of the Soviet Union, and finally, the now established internal pattern of criminalization of migrants in Italy were all factors. The fourth and final phase undeniably started with conflicts in Africa coupled with neoliberal austerity and significant levels of poverty combined with the Arab Spring, which prompted, in the years to follow, some of the largest human flows globally and historically. That period was also marked by growing disagreements between Italy and other countries of the EU, as well as with other international organizations.

At least three over-arching characteristics have persisted and have had influence throughout Italy's history of migration policy. The first was the country's persistent precarious socio-political and economic situation (Abbondanza, 2017, p. 88). With fragile and fast changing 
governments, Italy had difficultly focusing on importantly correlated socio-economic spheres such as welfare and its economy. Similarly, its policies pertaining to migration were often amended, but arguably never perfected. This significantly influenced the way Italy was able to deal with migration. The second was the ever-growing ratio of irregular migrants both entering and already present within the country, with which Italy could only deal with via amnesties. Third, Italy's established pattern of criminalization of migrants influenced the country's policies, with each new law becoming increasingly restrictive towards migrants. Altogether, these characteristics help explain Italy's position and the dichotomic new laws and amendments that occurred to its immigration policies over the years. Regardless of the ideological position of the governments in power, there is a pattern of increased restrictions while contrastingly giving Amnesty, often to hundreds of thousands of irregular immigrants at a time.

Arrivals to Italian borders peaked in the years 2013 to 2016, with over 1 million migrants entering the country irregularly (United Nations High Commissioner for Refugees, 2019). During the following year (2017), Italy unofficially renewed ties with Libyan forces in order to halt migration flows from Libyan shores, which resulted in a dramatic decrease in arrivals despite the controversy. To the present day, even though the numbers of arrivals slowly but consistently decreased, it is estimated that Italy still has received over $65 \%$ of by-sea migration flows in Europe (United Nations High Commissioner for Refugees, 2019). Thus, the size of migration flows Italy receives every year continues to be significant when compared to the rest of the EU.

Italy's current government is accused of promoting xenophobia and racism, which is reflected in the policy they are developing and the action they use to implement these policies. However, the government argues that its actions are "not racist", and that it accepts legitimate 
refugees, as well as delineates corresponding governmental responsibilities towards them. Italy justifies this position by condemning the lack of help with migrants' management from the EU, and challenges the constant criticism of the country's migration policies and management by observers and the international community (Winfield, 2018). Italy's leaders claim the EU should take on a greater share of the burden of the refugees' arrivals to its shores, for example by helping in the negotiations with migrants' home countries and helping in the return of those who do not qualify as refugees (Winfield, 2018). Ultimately, Italy claims that the "pretend solidarity" of the EU resulted in the country being overwhelmed by the migration flows, which ultimately lead to the over-burdening of its system. In other words, they blame the EU and a lack of their help for their own failure to effectively deal with migration to their country (Winfield, 2018).

Ultimately, it seems that Italy is both following the global status quo concerning migrants, while also pushing against global notions of morality when it comes to migration policy and management. It is undoubtedly part of what scholars identify as a European "farright" movement against migrants (BBC News, 2019). Under the League and the Five Star Movement's leadership, Italy has so far stayed true to its historical tendencies of dealing with migration in dichotomic, controversial ways by drafting its migration policies and laws in a reactionary, unplanned and un-analyzed way - all of which promises to continue to create chaos rather than help the "migration crisis" that it faces. From a broader perspective, The European Union has also arguably failed to help with the situation by letting Italy, a country with a near stagnant economy, a historically poorly-effective migration policy, and an apparently racist government, deal with the substantial migration flows. The extent of the consequences of Italy's anti-immigrant policies are still under study, and will likely do much damage before a solution is found. As demonstrated in this paper, the position that Italy has taken in the face of large 
migration flows, especially since the 2000's, has only worked to further socially, economically, and legally ostracize many already vulnerable migrants. Italy is now only one part of the rise of an anti-immigrant sentiment in Europe, with the consequences to ultimately affect the global situation.

Some of the limitations of this paper pertain to the fact that unrest in Africa and the Middle East, migration flows into Italy and across the rest of Europe, as well as political dynamics in Italy and are ever-evolving elements that cannot be addressed in this paper's limited space. For instance, neo-liberal austerity continues to create significant poverty in the Global South leading to continued displacement and forced migrations of enormous numbers of people. Nearly every day, new factors come into play and could affect the developments of Italy's migration and asylum policies, and by extension the treatment migrants receive when they enter Italy's borders. Some of the recent developments in Italy in 2019 were the interdiction of rescue ships into its territory, and to disembark migrants rescued at sea, mediatized stories reporting unlawful detention of asylum seekers, and clear violations of the international non-refoulement laws (Human Rights Watch, 2019). Finally, the full repercussions of the recent fall of Italy's government in August 2019 have yet to fully materialize, while the climate surrounding migrants remains precarious and their situation desperate (Horowitz, 2019). Thus, how Italy's new migration policies will affect the upcoming migration, as well as migrants already inside the country's borders, and vice-versa, has yet to fully play out.

The current situation in Italy, in reference to this paper and its limitations, leaves the door open for further, significant and relevant questions to be analyzed in the future. For example, an in-depth analysis of the effects of transitory migration, specifically, on migration and asylum policies in general, and perhaps even more broadly on migration policies across Europe, would 
be relevant on its own, as well as contributing to the understanding of the themes discussed in this paper. Moreover, a comprehensive analysis of the debate on migration management and responsibility of asylum seekers in Europe, between Italy, the European Union, as well as the rest of the International community, could inform on the future issues of human displacements in Europe. Ideally, a greater examination of the impact of xenophobia and racism in Italy on migrants and refugees would also highlight the impact xenophobic government policies have on marginalized communities.

Nonetheless, the analysis I conducted on Italy's migration policies permitted the identification of relevant characteristics such as the dichotomic manner with which it has tackled both migration and immigration, relationally, at every amendment to its laws and implementation of new policies, regardless of the ideological position of its governments (i.e. how Italy increased border control, yet provided Amnesty to those already inside the country, making them immigrants, officially, and thereby tackling both migration and immigration policy in relation to one-another). Understood as poorly managed migration and immigration, the dichotomic patterns mentioned in this paper allow a clearer understanding of the evolution of the rather hostile and chaotic climate surrounding migration and asylum that exists in Italy. The thematic analysis of the factors that influenced the evolution of migration policies and laws in Italy certainly informs the current climate in the country. To conclude, the sheer size of migration flows and the significance of the other difficulties Italy faces in dealing with the former warrants further research. 


\section{Bibliography}

Abbondanza, G. (2017). Italy's migration policies combatting irregular immigration: From the early days to the present times. The International Spectator, 52(4), 76-92.

doi: $10.1080 / 03932729.2017 .1384606$

AEDH - Association Europeenne pour la Defense des Droits de l'Homme. (2017). The new European operation Frontex Plus/Triton: An operation with differing objectives and more limited means than the Mare Nostrum operation. Asylum and Migration Policy. Retrieved from http://www.aedh.eu/The-new- European-operation-Frontex.html

Amnesty International. (2006). Annual report: The state of the world's human rights. [pdf]. Retrieved from https://www.amnesty.org/download/Documents/POL1000012006ENGLISH.PDF

Amnesty International. (2012). Italy: 'Historic' European Court judgment upholds migrants' rights. [pdf]. Retrieved from https://www.amnesty.org/en/latest/news/2012/02/italyhistoric-european-court-judgment-upholds-migrants-rights/

Amnesty International. (2014). Italy: Ending Mare Nostrum search and rescue operation would put lives at risk. [pdf]. Retrieved from https://www.amnesty.org/en/latest/news/2014/10/italy-ending-mare-nostrum-search-andrescue-operation-would-put-lives-risk/

Amnesty International. (2016). Hotspot Italy: How Eu's flagship approach leads to violations of refugee and migrant rights. [pdf]. Retrieved from https://www.amnesty.org/download/Documents/EUR3050042016ENGLISH.PDF 
Association for Juridical Studies on Immigration - ASGI. (2016). Memorandum of understanding between the Italian public security department and the Sudanese national police: A reading guide. State Watch Organization. [pdf]. Retrieved from https://www.statewatch.org/news/2016/nov/asgi-italy-sudan-mou.pdf

Barigazzi, J. (2017, August 4). Italy sees unexpected reduction in Mediterranean migration flows. Politico. Retrieved from https://www.politico.eu/article/europe-sees-unexpectedreduction-in-mediterranean-migration-flows/

BBC News. (2019, Nov. 13). Europe and right-wing nationalism: A country-by-country guide. BBC News. Retrieved from https://www.bbc.com/news/world-europe-36130006

Bontempelli, S. (2009). Il governo dell'immigrazione in Italia: il caso dei «decreti flussi». Tutela dei diritti dei migrant. Retrieved from https://www.a-dif.org/wpcontent/uploads/2016/02/bontempelli_flussi.pdf

Boyle, P., Halfacree, K., \& Robinson, V. (1998). Exploring contemporary migration. Essex: Pearson Education Limited.

Caiola, A. (2017). The European parliament and the directive on combating terrorism. ERA Forum, 18(3), 409-424. doi:10.1007/s12027-017-0476-1

Camilli, A. \& D'Emilio, F. (2019, June 29). Captain of humanitarian rescue ship arrested after Italian police boat rammed. Global News. Retrieved from https://globalnews.ca/news/5445796/migrant-aid-ship-captain-arrested/

Caprioglio, C., Ferri, F., \& Gennari L. (2018, April 10). Detention and Selection: An Overview of the Italian Hotspot System. Border Criminologies - University of Oxford. Retrieved from https://www.law.ox.ac.uk/research-subject-groups/centre-criminology/centrebordercriminologies/blog/2018/04/detention-and 
Castellazzi, S. (2010). Le implicazioni legislative del fenomeno sociale migratorio: L'evoluzione normativa italiana. In V. Gasparini Casari (ed.). Il diritto dell'immigrazione. Profili di Diritto Italiano, Comunitario e Internazionale. (pp. 93-140) Modena: Mucchi Editore.

Dal Lago, A. (2004). Non-persone: L'esclusione dei migranti in una società globale. Milan: Feltrinelli.

Davies, L. (2013, Oct. 3). Lampedusa boat tragedy is 'slaughter of innocents' says Italian president. The Guardian. Retrieved from https://www.theguardian.com/world/2013/oct/03/lampedusa-boat-tragedy-italy-migrants

Davies, L. (2014). Italy: end of ongoing sea rescue mission 'puts thousands at risk'. The Guardian. Retrieved from https://www.theguardian.com/world/2014/oct/31/italy-seamission-thousands-risk

Di Bello, M. (2000). La devianza degli immigrati: Il ruolo delle organizzazioni criminali. L'altro diritto - Centro di ricerca interuniversitario su carcere, devianza, marginalità e governo delle migrazioni. [pdf]. Retrieved from http://www.adir.unifi.it/rivista/2000/dibello/index.htm

Doctors Without Borders - MSF. (2018). Informal Settlements: Social marginality, obstacles to access to healthcare and basic needs for migrants, asylum seekers and refugees Italy. Report. [pdf]. Retrieved from https://www.msf.org/italy-migrants-and-refugees-marginssociety

European Parliament (2016). On the frontline: The hotspot approach to managing migration. Directorate-General for Internal Policies [pdf]. Retrieved from http://www.europarl.europa.eu/RegData/etudes/STUD/2016/556942/IPOL_STU(2016)55 6942_EN.pdf 
Fonte, G. \& Balmer, C. (2018). Italy pensions chief criticizes government over migrants, planned reforms. Reuters. Retrieved from https://www.reuters.com/article/us-italy-pensions/italypensions-chief-criticizes-government-over-migrants-planned-reforms-idUSKBN1JU1L8

Freeman, G. P., Kessler, A. E. (2008). Political economy and migration policy. In Arango J. et al. (Eds.), Journal of Ethnic and Migration Studies, 34(8), (pp. 655-678). London: Taylor \& Francis.

Gayle, D. (2015, April 15). Hundreds of migrants believed to have drowned off Libya after boat capsizes. The Guardian. Retrieved from https://www.theguardian.com/world/2015/apr/14/400-drowned-libya-italy-migrant-boatcapsizes

Giuffrida, A. (2018, Sept. 24). Italian government approves Salvini bill targeting migrants. The Guardian. Retrieved from https://www.theguardian.com/world/2018/sep/24/italiangovernment-approves-bill-anti-migrant-measures-matteo-salvini

Global Detention Project. (2018) Country profile: Italy. [pdf]. Retrieved from https://www.globaldetentionproject.org/countries/europe/italy

Glynn, I. (2016). Asylum policy, boat people and political discourse: Boats, votes and asylum in Australia and Italy. London: Palgrave Macmillan.

Horowitz, J. (2019, Aug. 20). Italy's Government Collapses, Turning Chaos Into Crisis. The New York Times. Retrieved from https://www.nytimes.com/2019/08/20/world/europe/italypm-giuseppe-conte-resign.html

Human Rights Watch. (2016). Italy: Children stuck in unsafe migrant hotspot. Retrieved from https://www.hrw.org/news/2016/06/23/italy-children-stuck-unsafe-migrant-hotspot 
Human Rights Watch - HRW. (2019). Italy events of 2018: Part of the EU Chapter. World Report 2019. Retrieved from https://www.hrw.org/world-report/2019/countrychapters/italy

Iacobini de Fazio, M. (2019, Feb. 01). After 'Salvini decree' evictions, refugees in Italy face an uncertain future. Public Radio International. Retrieved from https://www.pri.org/stories/2019-02-01/after-salvini-decree-evictions-refugees-italy-faceuncertain-future

Italian Council of Refugees \& Association for Legal Studies on Immigration. (2018). Country Report: Italy. Asylum Information Database (AIDA) and European Council on Refugees and Exiles (ECRE). [pdf]. Retrieved from https://www.asylumineurope.org/reports/country/italy

Italian Interior Ministry. (2013). Schema di Capitlio de appalto per la gestione dei centri de accoglienza per immigrati. [pdf]. Retrieved from http://www.prefettura.it/FILES/AllegatiPag/1192/Allegato2_SCHEMA_DI_CAPITOLA TO_DI_APPALTO_PER_LA_GESTIONE_DEI_CENTRI_DI_ACCOGLIENZA_PER_ IMMIGRATI.pdf

Italian Parliament - Senate of the Italian Republic (n.d.) Parliamentary Information, Archives and Publications Office of the Senate Service for Official Reports and Communication [pdf]. Retrieved from https://www.senato.it/documenti/repository/istituzione/costituzione_inglese.pdf 
Jones, G. (2018, June 04). Italy will no longer be 'Europe's refugee camp', vows new government. Reuters. Retrieved from https://www.reuters.com/article/us-italypolitics/italy-will-no-longer-be-europes-refugee-camp-vows-new-governmentidUSKCN1J017Z

Lombardi, B. (2011). The Berlusconi Government and intervention in Libya. The International Spectator, 46(4), 31-44. doi:10.1080/03932729.2011.628090

Martone, V. (2016). Marketization of social services and mafia infiltration: The case of migrants reception centers in Rome. The European Review of Organized Crime. Retrieved from https://www.academia.edu/33859451/Marketisation_of_Social_Services_and_Mafia_Infi Itration_Marketisation_of_Social_Services_and_Mafia_Infiltration_The_Case_of_Migra nt_Reception_Centres_in_Rome_by_Vittorio_Martone

Monitoring Center on Judicial Control of Migrants' Removal. (2016). Executive Summary: Italy. [pdf]. Retrieved from https://lexilium.it.pubblicazioni

Nallu, P. (2019). Europe's migration tourniquet comes full circle. Open Democracy: Free thinking of the world. [pdf]. Retrieved from https://www.opendemocracy.net/en/caneurope-make-it/europes-migration-tourniquet-comes-full-circle/

Palys, T. S. (2015). Research decisions: Quantitative, qualitative, and mixed method approaches, (Fifth ed.). Vancouver: Simon Fraser University Press.

Quadroni, A. \& Luppi, M. (2016, Nov. 10). Il "giro dell'oca” dei trasferimenti coatti dal Nord Italia a Taranto. Open Migration. ( Retrieved from https://openmigration.org/analisi/ilgiro-delloca-dei-trasferimenti-coatti-dal-nord-italia-a-taranto/ 
Stille, A. (2018, Aug. 09). How Matteo Salvini pulled Italy to the far right. The Guardian. Retrieved from http://ezproxy.lib.ryerson.ca/login?url=https://search-proquestcom.ezproxy.lib.ryerson.ca/docview/2086028874?accountid=13631

Strickland, P. (2018, June 09). Far-right calls to register Roma 'echoes' Europe's dark history. Al Jazeera. Retrieved from https://www.aljazeera.com/news/2018/07/calls-register-romaechoes-europe-dark-history-180705171831676.html

Sunday Independent. (2018, Jul. 01). Salvini, Italy's minister of fear and the new fascism. Sunday Independent. Retrieved from http://ezproxy.lib.ryerson.ca/login?url=https://search-proquestcom.ezproxy.lib.ryerson.ca/docview/2062095833?accountid=13631

Tintori G., Romei V. (2017) Emigration from Italy after the crisis: The shortcomings of the brain drain narrative. In J.M Lafleur \& M. Stanek (Eds.), South-North migration of EU citizens in times of crisis. (pp. 49-64). New York: Springer Cham.

United Nations High Commissioner for Refugees - UNHCR. (2016). Italy sea arrivals: Dashboard. [pdf]. Retrieved from https://data2.unhcr.org/en/documents/download/67555 United Nations - UN. (2019). Italy: UN experts condemn bill to fine migrant rescuers. Office of the High Commissioner of Human Rights. Retrieved from https://www.ohchr.org/EN/NewsEvents/Pages/DisplayNews.aspx?NewsID=24628\&Lang ID

United Nations High Commissioner for Refugees - UNHCR. (2019). Sea arrivals data: Italy. Operational Portal of Refugees Situation. Retrieved from https://data2.unhcr.org/en/situations/mediterranean/location/5205 
Veugelers, J. (2007). Recent immigration politics in Italy: A short story. Western European Politics, 17(2), 33-49. doi:10.1080/01402389408425013

Winfield, N. (2018, June 06). Italian leader says refugee policy in EU a 'failure'. The Windsor Star. Retrieved from http://ezproxy.lib.ryerson.ca/login?url=https://search-proquestcom.ezproxy.lib.ryerson.ca/docview/2051038893?accountid=13631 